\title{
Mammalia, Chiroptera, Molossidae, Tadarida brasiliensis I. Geoffroy, 1824: Distribution extension
}

\author{
Marcela Janina Nabte ${ }^{1,2, *}$, Analía Andrade ${ }^{1,2}$, Adrián Monjeau ${ }^{3}$, José Luis Hernandez ${ }^{4}$, Daniel Vaquero ${ }^{4}$ \\ and Sergio Leonardo Saba ${ }^{1,2}$ \\ 1 Centro Nacional Patagónico (CENPAT-CONICET). Boulevard Almirante Brown 2915, (9120). Puerto Madryn, CH, Argentina. \\ 2 Universidad Nacional de la Patagonia San Juan Bosco, Sede Puerto Madryn, Facultad de Ciencias Naturales. Boulevard Almirante Brown 3700, \\ (9120). Puerto Madryn, CH, Argentina. \\ 3 Universidad Atlántida Argentina, Sede Mar del Plata, Instituto de Análisis de Recursos Naturales. Arenales 2740, (7600). Mar del Plata, BA, \\ Argentina. \\ 4 Dirección de Turismo de Rada Tilly. Almirante Brown 117, (9001). Rada Tilly, CH, Argentina. \\ * Corresponding author. E-mail: nabte@cenpat.edu.ar
}

ABSTRACT: Tadarida brasiliensis is one of the most widely distributed mammalian species in America. We report the southernmost continental record for this species in Rada Tilly, province of Chubut, Argentina, extending its range ca. 390 $\mathrm{km}$ to the south.

Tadarida brasiliensis (I. Geoffroy, 1824) is a mediumsized bat, with characteristic parallel furrows on the internal surface of its large and rounded ears. It has a square tragus well developed and lips with deep vertical extensible grooves. The body color is variable within shades of brown and gray (Barquez et al. 1999; Parera 2002). Tadarida brasiliensis is a migratory species that forms large colonies with millions of individuals and occupies several types of roosts, including caves and natural crevices, buildings, and roofs of houses (Parera 2002). It feeds mainly on insects and is often preyed by owls and wild or domestic cats (e.g. Massoia 1989; Trejo and Lambertucci 2007).

Tadarida brasiliensis is easily recognizable among other patagonian small bats (e.g. Histiotus montanus) on the basis of the following cranial characters: the rostrum is narrow and the lachrymal furrow is visible. The canine is long and pointed. The first premolar (P1) is almost imperceptible, its height barely surpassing the cingulum of the canine. The P2 has a high protocone. The first molar (M1, absent in the study specimen) and M2 are essentially identical and have four commissures; the protocone and the hypocone (Hy) are well developed. The M3 has only three commissures and the hypocone is absent (Barquez et al. 1999) (Figure 1).

Among the mammals thatinhabit America, T. brasiliensis is one of the most widely distributed species. It occurs from Oregon, southern Nebraska, and Ohio (USA) to Greater and Lesser Antilles, and extends southward along the slopes of the Andes in Colombia, Ecuador and Perú towards Chile, Bolivia, southern Paraguay, southern Brazil and Argentina (Wilkins 1989; Barquez et al. 1999; Simmons 2005). In Argentina, the known geographic distribution for $T$. brasiliensis is based on numerous records, from the north to about $42^{\circ} \mathrm{S}$ in the south (Barquez et al. 1999). Daciuk (1974) registered this species in Puerto Madryn. On the other hand, Hill (1988) mentions a specimen for the Malvinas Islands.

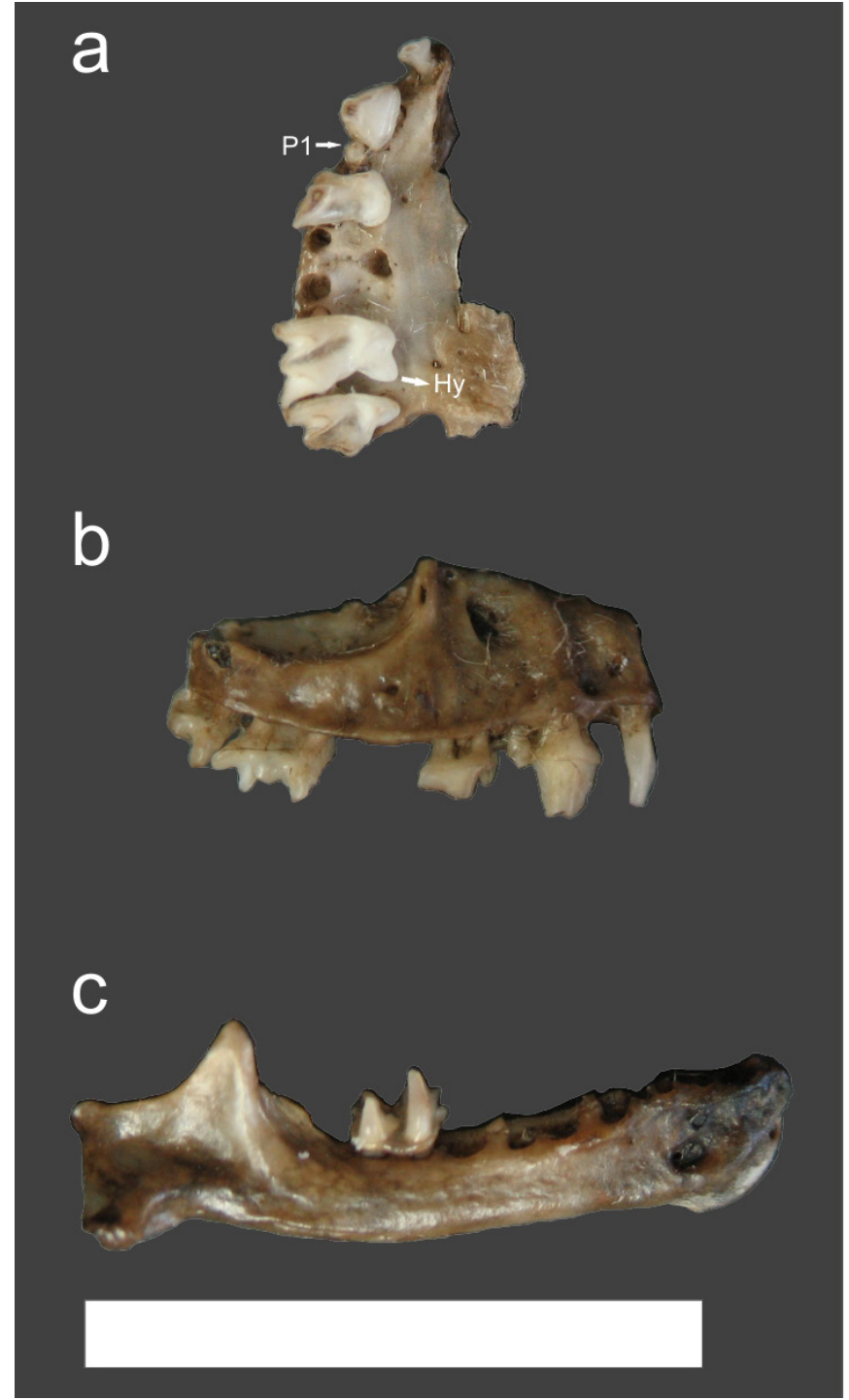

FIGURE 1. Maxillary bone ( $a$, ventral view; b, lateral view) and right mandible with incomplete tooth row (c, lateral view) of Tadarida brasiliensis from Rada Tilly, Chubut, Argentina (MN-E 136). Abbreviations: P1: first premolar; Hy: hypocone. Scale $=10 \mathrm{~mm}$. 


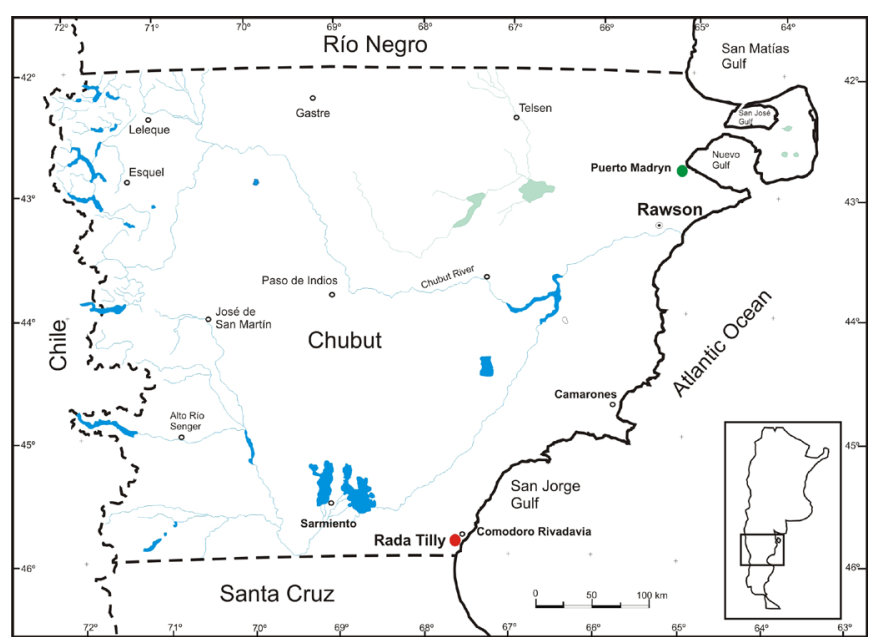

FigurE 2. New locality record (indicated with a red circle) for Tadarida brasiliensis in Rada Tilly, Chubut, Argentina, and the previous southernmost locality (green circle).

Here we report a new locality record for $T$. brasiliensis in Patagonia. Crania and mandible remains were recovered from a Magellanic Horned Owl (Bubo magellanicus; Aves, Strigidae) pellet sample, collected in September 2007 in southwest Rada Tilly, Chubut (455' $28.76^{\prime \prime}$ S, $67^{\circ} 34^{\prime} 38.53^{\prime \prime}$ W; Figure 2). This area is located within the limits of the Patagonian Phytogeographical Province (sensu León et al. 1998) and is characterized primarily by Atriplex lampa, Festuca argentina and Grindelia chiloensis.

Osteological remains picked apart from the pellet sample were identified by comparison with reference material housed at the Colección de Zooarqueología y Zoología, Unidad de Antropología y Arqueología, Centro Nacional Patagónico, Puerto Madryn, Argentina, and with specific literature (Barquez et al. 1999). The examined specimen is housed in this collection, and the collector's field number assigned to the owl pellet sample is MN-E 136.
The new locality reported herein constitutes the southernmost continental record for $T$. brasiliensis, extending its range $c a .390 \mathrm{~km}$ from the previous known southern locality (Daciuk 1974).

ACKNowledgments: The authors thank to Mariano L. Merino and an anonymous reviewer for their suggestions. This work was supported by Consejo Nacional de Investigaciones Científicas y Técnicas (CONICET, Argentina).

\section{LITERATURE Cited}

Barquez, R.M, M.A. Mares and J.K. Braun. 1999. The bats of Argentina. Special publications, Museum of Texas Tech University 42: 1-275.

Daciuk, J. 1974. Notas faunísticas y bioecológicas de Península Valdés y Patagonia. XII. Mamíferos colectados y observados en la Península Valdés y zona litoral de los Golfos San José y Nuevo (Provincia de Chubut, República Argentina). Physis Sección C 33: 23-39.

Hill, J.E. 1988. A bat from the Falkland Islands. Bat News 15: 6.

León, R.J.C., D. Bran, M. Collantes, J.M. Paruelo and A. Soriano. 1998. Grandes unidades de vegetación de la Patagonia extra andina; p. 125144 In M. Oesterheld, M.R. Aguiar and J.M. Paruelo (ed.). Ecosistemas patagónicos. Ecología Austral 8(2).

Massoia, E. 1989. Animales depredados por Tyto alba tuidara en la Ciudad de San Miguel, partido de General Sarmiento, provincia de Buenos Aires. Boletín Científico de la Asociación para la Protección de la Naturaleza 15: 2-7.

Parera, A. 2002. Los mamíferos de la Argentina y la región austral de Sudamérica. Buenos Aires: Editorial El Ateneo. 453 p.

Simmons, N.B. 2005. Order Chiroptera; p. 312-529 In D.E. Wilson and D.M Reeder (ed.). Mammal species of the World: a taxonomic and geographic reference. Baltimore: Johns Hopkins University Press.

Trejo, A. and S. Lambertucci. 2007. Feeding habits of barn owls along a vegetative gradient in northern Patagonia. Journal of Raptor Research 41: 277-287.

Wilkins, K.T. 1989. Tadarida brasiliensis. Mammalian Species 331: 1-10.

RECEIVED: September 2010

LAST REVISED: March 2011

ACCEPTED: March 2011

Published ONLINE: March 2011

EDITORIAL RESPONSIBILITY: Marcelo R. Nogueira 